DOI: $10.47743 /$ jss-2021-67-4-17

\title{
Falsul informatic. Interferenţe şi conexiuni cu alte infracţiuni
}

\section{Computer Related Forgery. Interference and Connections With Other Crimes}

\section{Ruxandra Răducanu ${ }^{1}$}

Rezumat: Infracţiunea de fals informatic reprezintă o incriminare nouă care conţine elemente ce se regăsesc şi în conţinutul altor infracţiuni, motiv pentru care, în practica judiciară s-a pus problema delimitării corecte a acestei infracţiuni de celelalte asemănătoare. Datele necorespunzătoare adevărului care rezultă în urma acţiunii tipice pot conduce la ideea inducerii în eroare, scopul de a produce consecinţe juridice poate echivala cu scopul de a obţine un folos patrimonial etc. Acest articol îşi propune să stabilească criterii clare care să evidenţieze particularitatea acestei incriminări, să o delimiteze, fără echivoc, de altele asemănătoare, luând în calcul obiectul juridic al acesteia şi specificitatea elementului său material.

Cuvinte-cheie: fals informatic; fraudă; pagubă; date informatice; acces ilegal la un sistem informatic

\begin{abstract}
The crime of tampering with computer data is an incrimination that contains elements that are also found in the content of other crimes, which is why, in judicial practice, the issue of the correct delimitation of this crime from other similar ones has been raised. Data that do not correspond to the truth resulting from the typical action may lead to the idea of misrepresentation, the purpose of producing legal consequences may be equivalent to the purpose of obtaining a patrimonial benefit. This study aims to establish clear criteria that highlight the particularity of this incrimination, to delimit it, unequivocally, from similar ones, taking into account its legal object and the specificity of its material element.
\end{abstract}

Keywords: tampering with computer data; fraud; damage; computer data; illegal access to a computer system

Infracţiunea de fals informatic completează capitolul falsurilor în înscrisuri, oferindu-se astfel protecţie şi acelor relaţii sociale care privesc încrederea publică în autenticitatea şi veridicitatea datelor informatice. Intenţia legiuitorului a fost de a acoperi toate fațetele prin care pot fi contrafăcute, falsificate înscrisurile, datele

\footnotetext{
${ }^{1}$ Profesor univ. dr., Facultatea de Drept, Universitatea din Craiova, e-mail: ruxandra.raducanu@edu.ucv.ro.
} 
informatice fiind considerate drept „înscrisuri electronice”2 . Apare, aşadar, firească opţiunea legiuitorului de a prelua această incriminare din legea specială, aşezarea ei în completarea falsurilor în înscrisuri, făcând vizibil cu uşurinţă obiectul juridic al acesteia.

În dorinţa sistematizării legii penale, Codul penal din 2009 a preluat mai multe incriminări din legi speciale. Un exemplu în acest sens este infracţiunea de fals informatic reglementată de dispoziţiile art. 325 C.pen. potrivit cărora „Fapta de a introduce, modifica sau şterge, fără drept, date informatice ori de a restricţiona, fără drept, accesul la aceste date, rezultând date necorespunzătoare adevărului, în scopul de a fi utilizate în vederea producerii unei consecințe juridice, constituie infracțiune şi se pedepseşte cu închisoarea de la unu la 5 ani”. Reglementarea iniţială se regăsea în Legea nr. 161/2003, Titlul III, art. 48, iar în actuala reglementare singura modificare priveşte limitele pedepsei, care au fost reduse.

Pentru comiterea infracţiunii de fals informatic este necesar să existe un sistem informatic funcţional, neputându-se lua în discuţie existenţa acestei infracţiuni în cazul inexistenţei unui sistem informatic în funcţiune ${ }^{3}$. Această cerinţă preexistentă poate, în aparenţă, să pună în discuţie opţiunea legiuitorului de reglementare a acestei infracţiuni în cadrul Titlului VI - Infracţiuni de fals, capitolul III - Falsuri în înscrisuri, de vreme ce în Titlul II - Infracţiuni contra patrimoniului, se regăseşte un capitol distinct, capitolul IV, destinat fraudelor comise prin sisteme informatice şi mijloace de plată electronice. Obiectul juridic al infracţiunii de fals informatic, rezultatul acesteia care se grefează pe încrederea publică în veridicitatea datelor informatice sunt argumente care justifică necesitatea încadrării acestei infracţiuni drept o infracţiune de fals. De altfel, datele necorespunzătoare adevărului trebuie să se subsumeze scopului de a putea fi folosite în vederea producerii unei consecinţe juridice, scop întâlnit şi în materia infracţiunii de fals material în înscrisuri oficiale.

$\mathrm{Cu}$ toate acestea, situaţia premisă a infracţiunii poate conduce la dificultăţi de încadrare şi la nevoia creării unor criterii clare de diferenţiere între infracţiunea de fals informatic de cea de fraudă informatică sau de alte infracţiuni contra siguranţei şi integrităţii sistemelor şi datelor informatice. Unele din cerinţele esenţiale pentru existenţa infracţiunii de fals informatic, cum ar fi săvârşirea faptei fără drept, datele necorespunzătoare adevărului care sunt rezultate din oricare din acţiunile incriminate, fac o diferenţă clară faţă de alte infracţiuni.

Astfel, delimitarea clară de alte incriminări asemănătoare trebuie să aibă în vedere prezenţa şi analiza unor cerinţe specifice infracţiunii de fals informatic.

Cele mai multe discuţii privesc raportul dintre infracţiunea de fals informatic şi cea de fraudă informatică, putând exista confuzie între cele două incriminări sau,

${ }^{2}$ C. Rotaru, A.-R. Trandafir, V. Cioclei, Drept penal. Partea specială II, Editura C.H. Beck, București, 2016, p. 386.

${ }^{3}$ G. Antoniu, T. Toader, V. Brutaru, Șt. Daneș, C. Duvac, I. Griga, I. Ifrim, Gh. Ivan, G. Paraschiv, I. Pascu, I. Rusu, M. Safta, I. Tanasescu, I. Vasiu, Explicațiile noului Cod penal, vol. IV, Editura Universul Juridic, București, 2016, p. 548. 
dimpotrivă, concurs, fiind reţinută şi soluţia absorbiei falsului informatic în infracţiunea de fraudă informatică.

În aceste condiţii, dacă ne referim la infracţiunea de fraudă informatică, potrivit dispoziţiilor art. 249 C.pen., aceasta constă în „introducerea, transmiterea, modificarea sau ştergerea de date informatice, restricţionarea accesului la aceste date ori împiedicarea în orice mod a funcţionării unui sistem informatic, în scopul de a obţine un beneficiu material pentru sine sau pentru altul, dacă s-a cauzat o pagubă unei persoane".

Apreciem că cel mai important element care nu trebuie uitat şi nici neglijat priveşte stabilirea clară a valorii sociale protejate în cazul celor două infracţiuni. Frauda informatică reprezintă o infracţiune îndreptată împotriva patrimoniului, prin care se doreşte protejarea „integrităţii datelor informatice, securităţii sistemelor informatice şi patrimoniului unei persoane"4. De altfel, securitatea sistemelor informatice este inclusă în obiectul juridic al infracţiunii şi în opinia altor specialişti ${ }^{5}$. Spre deosebire, infracţiunea de fals informatic urmăreşte să protejeze încrederea publică în autenticitatea datelor informatice stocate într-un sistem informatic.

Este adevărat că modalităţile în care se poate comite elementul material al falsului intelectual se regăsesc şi în elementul material al infracţiunii de fraudă informatică, însă această împrejurare nu anulează valorile sociale diferite care sunt protejate prin cele două norme, care sunt evidenţiate şi de reglementarea lor în alte grupe de infracţiuni şi care impun soluţia concursului de infracţiuni pentru a asigura protejarea completă a valorilor sociale încălcate prin săvârşirea faptei.

De aceea, în doctrină $\breve{b}^{6} \mathrm{~s}$-a apreciat că şi în situaţia în care sunt prezente elemente comune celor 2 infracţiuni (o modalitate comună a elementului material, producerea unei pagube, date necorespunzătoare adevărului, scopul obţinerii unui beneficiu), se menţine soluţia concursului de infracţiuni, deoarece una este o infracţiune contra patrimoniului, iar cealaltă o infracţiune de fals.

Producerea pagubei, ca rezultat evident şi anume precizat în textul normei de incriminare a fraudei informatice este o diferenţă faţă de infracţiunea de fals informatic şi motivul pentru care, în practica instanţelor, de cele mai multe ori, cele două infracţiuni sunt reţinute în concurs. Astfel, s-a retinut ${ }^{7}$ concurs de infracţiuni în cazul „introducerii fără drept de date informatice şi a ataşării unei fotocopii a cărţii de identitate aparţinând altei persoane, precum şi a unui extras de cont modificat, pe numele acesteia pe platformele online ale unor instituţii financiare nebancare, rezultând date necorespunzătoare adevărului, respectiv atribuirea în fals a identităţii martorului, în scopul de a obţine un beneficiu material, respectiv contractarea unor împrumuturi în mod fraudulos, fiind cauzate pagube instituţiilor

${ }^{4}$ A. Boroi, Drept penal. Parte specială, Ed. 4, Editura C.H. Beck, București, 2019, p. 291.

${ }^{5}$ T. Toader, Drept penal român. Partea specială, vol. I, Editura Universul Juridic, București, 2019, p. 331.

${ }^{6}$ C. Rotaru, A.-R. Trandafir, V. Cioclei, op. cit., p. 389.

${ }^{7}$ Judecătoria Ploiești, sentința penală 1117/2021, [Online] la www.sintact.ro, accesat 08.12.2021. 
financiare nebancare". S-a reţinut ${ }^{8}$, de asemenea, concursul între cele 2 infracţiuni în cazul în care, în baza aceleiaşi rezoluţii infracţionale, s-a realizat introducerea fără drept de CNP-uri fictive aparţinând unor persoane inexistente şi modificarea, fără drept, a bazei de date a Agenţiei Judeţene pentru Plăţi şi Inspecţie Socială Maramureş, rezultând date necorespunzătoare adevărului şi, prin utilizarea aceluiaşi sistem informatic, au fost desfăşurate „activităţi ilicite specifice infracţiunii de fraudă informatică, constând în acte materiale distincte de a introduce şi modifica date informatice referitoare la programul privind alocaţia de stat pentru copii şi cel de indemnizaţie pentru creşterea copilului minor, cu scopul de a obţine un beneficiu material".

În practică sunt prezente şi soluţii argumentate în sensul absorbţiei infracţiunii de fals informatic în infracţiunea de fraudă informatică cu argumentarea că infracţiunea de „fals informatic este natural absorbită de infracţiunea de fraudă informatică, având în vedere că, în speţă, scopul activităţii infracţionale desfăşurate de inculpaţi a fost obţinerea unui beneficiu material. Pentru existenţa infracţiunii de fals informatic ar fi fost necesar ca fapta de a introduce, modifica, şterge date informatice să fie comisă cu scopul ca aceste modificări, în sens larg, să fie producătoare de consecinţe juridice, fără însă a se urmări în mod direct obţinerea unui beneficiu material"'. Soluţia se regăseşte şi în doctrină ${ }^{10}$, care apreciază că frauda informatică este o infracţiune complexă ce absoarbe în conţinutul său infracţiunea de fals informatic.

Considerăm că, desi elementul material al infracţiunii de fals informatic se regăseşte, parţial, în elementul material al infracţiunii de fraudă informatică şi se poate reţine şi prezenţa celorlate cerinţe necesare existenţei falsului informatic, absorbţia acestei infracţiuni în infracţiunea de fraudă informatică nu poate fi admisă. În obiectul juridic al infracţiunii de fraudă informatică nu este inclusă protejarea încrederii publice - valoare socială ocrotită în cazul falsului -, iar soluţia absorbţiei ar lipsi de sanç̧iune atingerea adusă acestei valori.

Dacă analizăm comparativ cele două reglementări, se poate observa că elementul material al infracţiunii de fraudă informatică presupune şi împiedicarea în orice mod a funcţionării unui sistem informatic, ceea ce subliniază încă o data că acţiunea făptuitorului vizează, în principal, funcţionarea sistemului informatic, iar acţiunile care privesc datele informatice (introducerea, transmiterea, modificarea sau ştergerea de date informatice, restricţionarea accesului la aceste date) nu sunt comise fără drept, cerinţă precizată expres pentru existenţa falsului informatic. Cerinţa producerii unei pagube nu este de natura infracţiunii de fals

${ }^{8}$ Tribunalul Maramureș, sentința 12/2015, [Online] la www.legeaz.net, accesat 08.12.2021.

${ }^{9}$ Curtea de Apel București, secția a-II-a penală, decizia 1472 din 25 octombrie 2017, [Online] la www.rolii.ro, accesat 08.12.2021.

${ }^{10}$ N. Neagu, Fraude comise prin sisteme informatice și mijloace de plată electronice variante speciale ale infracțiunii de inș̦elăciune?, Revista Română de Drept penal al afacerilor nr. 3/2019; V. Dobrinoiu, N. Neagu, Drept penal. Partea specială, Editura Universul Juridic, București, 2012, p. 272. 
informatic, însă cerinţa realizării fără drept a oricăreia din acţiunile incriminate este esenţială pentru existenţa faptei.

Însăşi urmarea imediată a infracţiunii de fals informatic - datele necorespunzătoare adevărului - evidenţiază obiectul juridic al acesteia, necesitatea protejării încrederii publice.

De altfel, cele două elemente - săvârşirea fără drept a acţiunii incriminate şi datele necorespunzătoare adevărului rezultate - sunt, în mod constant evidenţiate în practică şi apreciate ca fiind definitorii pentru existenţa infracţiunii de fals informatic. În cazul în care crearea unei pagini de facebook în a cărei titulatură se foloseşte sigla unei societăţi completată cu o sintagmă cu conotaţie negativă, cu scopul de a atenţiona pe ceilalţi în privinţa serviciilor neserioase oferite de firmă, s-a apreciat că fapta nu este de natură a induce în eroare opinia publică, nu se realizează fără drept, deoarece inculpatul nu şi-a însuşit paternitatea siglei şi nici nu are ca urmare date necorespunzătoare adevărului, de vreme ce comentariile negative ale inculpatului erau urmarea neîndeplinirii obligaţiilor contractuale de către firmă ${ }^{11}$. Lipsa acestor elemente din conţinutul faptei conduce la concluzia neprevederii faptei în legea penală şi la soluţia achitării inculpatului.

Trebuie reţinut şi aspectul că ori de câte ori producerea pagubei este urmarea unei acţiuni de inducere în eroare care nu are legătură cu datele informatice, soluţia concursului de infracţiuni între înşelăciune şi fals informatic se reţine. În practică s-a reţinut ${ }^{12}$ că în cazul postării unor anunţuri fictive pe diferite site-uri de internet în numele unor societăţi comerciale ce ofereau locuri de muncă în străinătate, anunţuri urmate de încheierea unor contracte de muncă false şi obţinerea unor comisioane drept compensaţie pentru prelucrarea dosarului de angajare, soluţia priveşte reţinerea concursului între înşelăciune şi fals informatic; s-a reţinut, de asemenea, aceeaşi soluţie, în cazul inducerii în eroare a părţii vătămate prin postarea pe reţeaua de internet a unui anunţ privind vânzarea unui tractor pe care inculpatul nu îl deţinea, având ca scop obţinerea de foloase materiale în mod fraudulos şi prejudicierea părţii văătămate ca urmare imediată. Având în vedere că frauda informatică fost privită ca o formă particulară de înşelăciune ${ }^{13}$, ca o variantă specială a infracţiunii de înşelăciune ${ }^{14}$, soluţia concursului falsului informatic cu infracţiunea de înşelăciune trebuie menţinută şi în cazul în care paguba este urmarea unui alt tip de înşelăciune - frauda informatică.

Şi în privinţa delimitării de infracţiunea de acces ilegal la un sistem informatic se poate pune problema confuziei între cele 2 infracţiuni, dar în structura infracţiunii de fals informatic nu este prevăzută condiţia accesării ilegale

${ }_{11}$ Curtea de Apel București, decizia nr. 1044/2017, [Online] la www.sintact.ro, accesat 08.12.2021.

${ }^{12}$ Curtea de Apel Timișoara, secția penală, decizia nr. 744/A/2016, [Online] la www.rolii.ro, accesat 08.12.2021; Tribunalul Olt, sentința penală nr. 284/2015, [Online] la www.sintact.ro, accesat 08.12.2021.

${ }^{13}$ Curtea de Apel Alba Iulia, s. pen., dec. nr. 821 din 10 octombrie 2017, [Online] la www.rolii.ro, accesat 08.12.2021.

${ }^{14}$ N. Neagu, op. cit. 
a sistemului informatic pentru a introduce, modifica sau şterge, fără drept, date informatice sau pentru a restricţiona, fără drept, accesul la aceste date, ceea ce înseamnă că există posibilitatea comiterii falsului de o persoană autorizată să acceseze sistemul. Recent, Înalta Curte de Casaţie şi Justiţie s-a pronunţat ${ }^{15}$ subliniind că noţiunea „fără drept” se raportează la datele informatice şi, prin urmare, la persoana care are dreptul de dispoziţie asupra acestor date, ceea ce face o diferenţă evidentă de infracţiunea de acces ilegal la un sistem informatic pentru care accesul este neautorizat. Mai mult, în cazul infracţiunii de fals informatic, nu are loc o intervenţie asupra unui sistem infomatic, ci acţiunea făptuitorului vizează şi se răsfrânge asupra datelor informatice, de aceea nu se poate vorbi de absorbţia infracţiunii de acces ilegal la un sistem informatic în falsul informatic, ci de concursul între cele 2 infracţiuni ${ }^{16}$.

Considerăm că şi în această privinţă, soluţia concursului de infracţiuni poate fi fundamentată pe diferenţa obiectului juridic al fiecărei incriminări din concurs, prin accesul ilegal la un sistem informatic urmărindu-se „ocrotirea domiciliului informatic"17, în timp ce la infracţiunea de fals informatic este evidentă nesocotirea încrederii publice în autenticitatea datelor informatice.

Discuţii pot să apară şi în legătură cu infracţiunea de alterare a integrităţii datelor informatice, reglementată de dispoziţiile art. 362 C.pen şi care constă în „fapta de a modifica, şterge sau deteriora date informatice ori de a restricţiona accesul la aceste date, fără drept”. Pe lângă faptul că modificarea, ştergerea datelor informatice sau restricţionarea accesului la acestea sunt întâlnite şi în elementul material al infracţiunii de fals informatic, toate aceste acţiuni tipice infracţiunii prevăzute de art. 362 sunt realizate fără drept, cerinţă întâlnită şi în elementul material al infracţiunii de fals informatic. Protecţia integrităţii datelor informatice se realizează prin incriminarea faptei de alterare a integrităţii datelor informatice, iar în situaţia în care acţiunile sunt săvârşite în scopul de a fi utilizate în vederea producerii unei consecinţe juridice, infracţiunea prevăzută de art. 362 C.pen. este absorbită în falsul informatic ${ }^{18}$, reţinându-se doar această din urmă infracţiune. În cazul în care făptuitorul nu şi-a propus să utilizeze datele necorespunzătoare adevărului în vederea producerii unei consecinţe juridice, lipsind scopul

15 Înalta Curte de Casație și Justiție, RIL nr. 4/2021, publicat în Monitorul Oficial nr. 171 din 19 februarie 2021, „Fapta de a deschide și utiliza un cont pe o rețea de socializare deschisă publicului, folosind ca nume de utilizator numele unei alte persoane și introducând date personale reale care permit identificarea acesteia, întrunește două dintre cerințele esențiale ale infracțiunii de fals informatic prevăzute în art. 325 din Codul penal, respectiv cea ca acțiunea de introducere a datelor informatice să fie realizată fără drept și cea ca acțiunea de introducere a datelor informatice să aibă ca rezultat date necorespunzătoare adevărului”.

${ }^{16}$ Curtea de Apel Craiova, decizia nr. 827/2021, [Online] la www.sintact.ro, accesat 08.12.2021.

${ }^{17}$ I. Vasiu, L. Vasiu, Informatică juridică și drept informatic, Editura Albastra, Cluj, 2002, p. 166.

${ }^{18}$ G. Antoniu, T. Toader ș.a, op. cit., p. 552. 
caracteristic falsului informatic, se va reţine infracţiunea de alterare a integrităţii datelor informatice.

În concluzie, infracţiunea de fals informatic reprezintă o incriminare distinctă, cu elemente particulare ce o diferenţiează de alte incriminări asemănătoare, ce presupune protecţia unei valori sociale bine evidenţiată, iar soluţia reţinerii în concurs cu infracţiunile menţionate anterior este justificată de argumente atât doctrinare, cât şi practice.

\section{Referinţe}

Antoniu G., Toader T., Brutaru V., Daneş Şt., Duvac C., Griga I., Ifrim I., Ivan Gh., Paraschiv G., Pascu I., Rusu I., Safta M., Tanasescu I., Vasiu I., Explicaţiile noului Cod penal, vol. IV, Editura Universul Juridic, Bucureşti, 2016

Boroi A., Drept penal. Parte specială, Ed. 4, Editura C.H. Beck, Bucureşti, 2019

Dobrinoiu V., Neagu N., Drept penal. Partea specială, Editura Universul Juridic, Bucureşti, 2012

Neagu N., Fraude comise prin sisteme informatice şi mijloace de plată electronice - variante speciale ale infracţiunii de înşelăciune?, Revista Română de Drept penal al afacerilor nr. $3 / 2019$

Rotaru C., Trandafir A.-R., Cioclei V., Drept penal. Partea specială II, Editura C.H. Beck, Bucureşti, 2016

Toader T., Drept penal român. Partea specială, vol. I, Editura Universul Juridic, Bucureşti, 2019

Vasiu I., Vasiu L., Informatică juridică şi drept informatic, Editura Albastra, Cluj, 2002 
